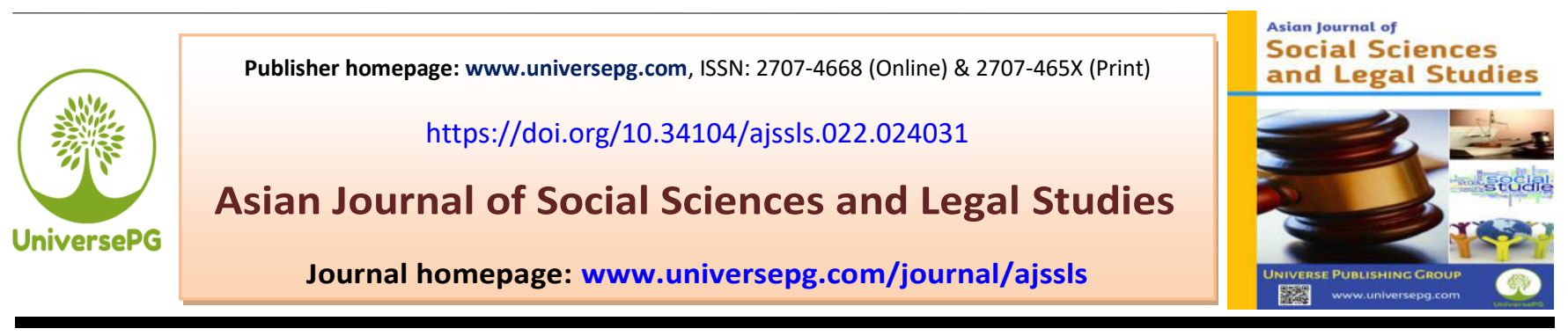

\title{
Religion from Sociological Perspectives: An Overview
}

\author{
Ram Proshad Barman* \\ Department of Sociology, Faculty of Social Science, Begum Rokeya University, Rangpur-5400, Bangladesh. \\ *Correspondence: rpbarman@ brur.ac.bd (Ram Proshad Barman, Assistant Professor, Department of Sociology, Faculty of \\ Social Science, Begum Rokeya University, Rangpur-5400, Bangladesh).
}

\begin{abstract}
The prime purpose of this article is to study religion from different paradigms or perspectives from a sociological viewpoint. Religion is defined as a social institution while economic reality, ideological support and everyday interactions of people are also undertaken as core concepts. In fact, this article is an overview of religion of three theoretical perspectives of sociology focusing on the work of Emile Durkheim, Robert K. Merton (the functionalist), Karl Marx, Max Weber, Friedrich Engels (the conflict), and Peter Berger (the interactionist). A brief discussion of each perspective is articulated clearly, followed by secondary sources including published books, book sections, blogs, research articles and WebPages highlighting the foundations of the relevant theory. Afterward, the author reviews the discourses of the theorists' regarding religion with its application to human society. Finally, the article provides a summary of these perspectives continuing to develop the field.
\end{abstract}

Keywords: Religion, Sociological Perspective, Functionalism, Conflict, Interactionism, and Doctrine.

\section{INTRODUCTION:}

In the globe, starting from ancient period people practice and follow religion in every walk of life, though the ways of worships demonstrate the differentiation in terms of territory and ethical issues. In Idowuian sense, it is stated that religion is very much with us (Idowu, 1973) and people should never ignore its importance even from the written of world history. Religion can be the certain elements that make some common and harmonious functions, are performed by people.

Even they share such things for working together comprising worship, priesthood, festivals, place of worship, objects of worship, code of conduct, prayer, music or songs, sacrifices, and symbolism (Anyanwu, 1999). In broad sense, religion can be defined from some existential questions and how an individual deals with such question in his or her daily life. These ques-

UniversePG I www.universepg.com tions sometimes known as predicament that arise from humans' consciousness. Existential questions for instance; a) What is the prime purpose and meaning of my life? b) What is my duty towards my parents? Such questions deeply engage us with some high power, supernatural power (God) that we follow in the form of symbol, myth and rituals (Batson and Stokes, 2004). Similarly, the functions of religion are different from one theorist to another for example; one doctrine emphasizes that religion provides social support in spiritual and material world in times of crisis; others reject it considering religion as the agent of conflict, although it does not show same behavior in the world at equal parameter. In this regard, Hoffman (2006) identifies that only religion is not fully responsible for conflicts rather political purposes are eminently motivated with the name of religion (Hoffman, 1993). Again, in some cases religion may not be the solely 
responsible for violence as Gurr ascertains that 'religion is rarely the root cause of conflict' (Gurr, 1993). Furthermore, people can easily learn from their fellow being, that can be performed by the communications, sharing ideas among individuals through daily interactions.

Therefore, in order to study any problems associated with religion and society, three major sociological perspectives the functionalist, the conflict and the interactionism are designed as core subject of discussion in this article.

\section{Importance of the Study}

The discussion of religion can be useful for understanding the theoretical base among students and teachers who relate themselves to learn the functions of religious organization. Again, the study will be helpful for the researchers for further studies in such kind of concept relevant to the society in a depth sense. Although many writers of the world give priority about the religious writing, in Bangladesh few researchers and academician has articulated such manuscript on the religion specially focusing the theoretical perspective of sociology. Realizing the fact, the author has composed the article.

\section{METHODOLOGY:}

This article follows the systematic review method because it helps the researcher to identify and appraise the research topics, as well as data collection, interpretation can be easy from earlier research (Snyder, 2019). The author has collected data from different secondary sources. All the secondary data are taken from published books, book chapters, conference works, seminar works, unpublished documents, webpages, blogs and research articles.

\section{Plan of discussion in the Study}

The study has been categorized into several parts for making the discussion easily. For instance; the importance of the study belongs to first part; the methodology belongs to second part and third is the theoretical perspective of sociology. Afterwards, three sub-sections are designed under sociological perspective. For example; functionalist, conflict and interactionist perspective and finally, conclusion is remarked (Miakhil et al., 2022).

UniversePG I www.universepg.com

\section{Theoretical Perspective of Religion}

In this information age, religion and its relevant studies has occupied a gentle place for social scientists, philosophers and sociologists while people comply on the major three theoretical views of studying sociology. In general, using the functionalism, conflict and symbolic interactionism perspective people can perceive the importance and existence of religion with other problems associated with it in a highly technical world (Emerson, Mirola and Monahan, 2016). Still different phenomenon remains beyond under control of human being towards religious belief and rituals; hence the curiosity of people in searching the impact of religion is ongoing. Although many scholars demonstrate rationale in response to multifarious asking relevant to belief system and functions of religion, there also doubt about strength of supports among religious leaders, critics followers in $21^{\text {st }}$ century because they consider religion a source either of violence or of reconciliation (Silvestri and Mayall, 2015). Nowadays, individuals may accept or reject easily the notions of various theorists' paradigm and doctrine for the development of social construction. Relying these issues, the three paradigms of religion are stated in this paper to earn knowledge about religion provided by renowned social theorists.

\section{Functionalist Perspective}

The functional doctrines unlike other theorists argue that religion always serves several functions in society. From the creation of the universe, religion has depth interconnectedness with the society the largest social system developed by human being. Both society and religion are interdependent for their existence because of the value induced by creators that relates humanity to spirituality (Council of Europe, 2022). This functionalist paradigm helps to answer many questions of critics regarding the role of religion. For instance; a) How the world has been created? b) Why do people suffer in the society? c) Is there a plan for our lives beyond social welfare? and d) Is there an afterlife?

According to this perspective, religion guides people to go with the pathways of Gods principles knowing the prime goals of the creation of the universe and the duties of individuals towards creator and society. Religious followers can avail enormous supports about the complexities associated with death and various con- 
cern of humanities creating a place for social interaction, social control like going to worship in temple or mosque daily or weekly that may vary on the basis of geography (Herzog et al., 2020). Again, functional theorists consider that to find the spiritual peace, comfort of body and mind, emotional support during insecure environment people apply religious guidelines onward. Even the rituals people practice often maintain organizational balance simultaneously socializing sexual behavior of the masses.

\section{Religion through the lens of Emile Durkheim}

Religion is studied by French sociologist Émile Durkheim (1858 - 1917) as a core concept for the societal welfare applicable from his period to current state of facts, while religion is of only a passing concern to Karl Marx. It is also discovered that Durkheim in his major work "The Elementary Forms of Religious Life" de-notes the ascriptions of religious values and ethics towards human society. For this reason, Durkheim desires to study Australian aborigines about their practices and belief system searching several doubts that is continuously imposed throughout aboriginal religious lives. Concurrently, it is regarded that aborigines practice very simple and mostly primitive forms of religion. But the European nations follow an updated form of religious life. Thence, Durkheim demonstrates the aspects of totem to find out the fascination associated with aboriginal religion (Durkheim, 1915). Interestingly, he further argues about totem and society in such way;

If the totem "is at once the symbol of the god and of the society, is that not because the god and the society are only one?" (Durkheim, 1915)

Accordingly, Durkheim reaches to a conclusion about the totems, objects and animals considering them as symbol particularly followed by a group or clan that actually nothing with supernatural things but a representation of the social group. Thus, even in European nations, Durkheim emphasizes that "the worship of God to be nothing more than the worship of society", (Durkheim, 1912). Again, his (Durkheim, 1915) another statement reflects that "things that surpass the limits of our knowledge', Defining religion as a unified system of beliefs and practices in which people relate them to sacred things, he asserts that sometimes people know little about it. In addition, setting reUniversePG I www.universepg.com gulations in what people are allowed or prohibited, religion provides the opportunity to establish moral unity among social groups most probably the organization namely a temple or church, mosque where people follow the rule of God and practice those beliefs. For the relationship between society and religion one can find that society is one of the most classical facts symbolized by the religious rites and rituals. In one hand, he substantiates that society has its own needs from religion because of reaffirmation the validity regarding totem or Gods about worship, praying to its members and followers. On the contrary, the Gods also symbolize society, defining the soul as the symbol of the social element within the individual that lives on long after the people themselves. Although few critics do the criticism on Durkheim's religious discussion, always remains in the field of philosophical thought, and doesn't consider it so much influential. Even, the ideology he develops towards religion functionally helps to meet the basic social needs establishing a sociological axiom.

\section{Religion through the lens of Robert K. Merton}

Afterwards, the contribution of Robert Merton (19572003) with the introduction of the concept of dysfunction, functional paradigm becomes more complex and sophisticated (Merton, 1957). Thus, it is now popular and one of the most widely used theoretical paradigms in the sociology of religion. For this, Merton identifies and critiques the role of various social organizations. In his view, social organizations like family, religion not only performs functions for the people of society but also, they may generate dysfunctions what exceedingly impacts the social bondage, glue and values of the standard of the entire society. Over the decades, functionalists have recognized multifarious functions and dysfunctions of religion (Hossain, 2020).

Following O'Dea (Sociology of religion), scholars often classify the human needs into two categories that religion actually does for instance; expressive and adaptive (O'Dea, 1966). With the help of religion people's various hard realties are supported by using the supernatural things emotionally. Even powerlessness, uncertainty, injustice, and the inevitability of death are being meaningful and purposive through the guidance of religion universally (Krok, 2015). For the 
functions of religion, functional theorist complies on the importance of values and norms that helps to maintain the social order through multidimensional forces. Moreover, they also rationalize the few rituals and beliefs which commonly set people to live in a roof under such social systems. It is undoubtedly true that each and every action of individuals may create dysfunction although aiming at functional at any situation. By enormous confrontation and misguidance people either can be weak or show discouragement to participate to the movement that actually brings the social change as well. So, followers of religion get the platform of being sacred themselves with strong engage the legitimate norms and values provided by the social organization over the time, make them revolutionary when it is needed for the larger social interest (Frost, 2005). Functional paradigm also insists that following religious rites, rituals and ceremonies, people avail strong support that can encourage them to develop a sense of better security and safety recognizing themselves as group solidarity rather individual. In another words, religion performs and promotes social control following the existing law regulating sexual behavior of the human being.

\section{Conflict Perspective}

Religion is identified as social institution by Conflict theorists unlike other perceptive does in general. Religion is viewed as responsible factor for creating and maintaining social inequality. Again, with the name of divine right the oppressors or exploited class continue to maintain unequal social structures for instance; caste system in Indian society. The Conflict theorists critically oppose the idea indicating few religions what recommends their followers by saying that they should be satisfied what they have and it's divinely chosen for them. And amazingly, various Christian institutions continue such situation for centuries so that they can make people understand that owing to their poverty they shouldn't raise voice rather their true reward will be given by God after death (McGivern, 2014). Another conflict views the feminist theory, emphasized on inequality specifically for gender. Feminist theorists argue that women play a vital role to the child socialization that links to the teachings of religion, but their contribution is not recognized rather they are treated very traditionally (Parpart, Connelly and Barriteau, 2000). So, they need to empower to the power practice and religious practice employing in various positions in society considering gender equality.

\section{Marxian View on Religion}

The philosopher, sociologist and economist Karl Marx (1818-1883) is the first sociological giants to consider the religious issues. His central thought conflict and economic determinism and its impact to the religion has added more particular attention among others theorist in $19^{\text {th }}$ century. In Marxian sense, Religion is only the part of the superstructure which is established and formatted from the economic realities at any part of the world. He also pretends that through ideological support people do little for their own from religion, rather no such independence they find to perform their daily actions. Nonetheless, only a very negative social role religion can play for the society and its mere followers.

Marx also identifies (1844, P. 122)) that religion acts as profound form of social alienation because -

"The worker is related to the product of his labor as to an alien object. ... The more the worker expends himself in work the more powerful becomes the world of objects which he creates in face of himself, the poorer he becomes in his inner life, and the less he belongs to himself. It's just the same as in religion. The more of himself man attributes to God the less he has left in himself'' (Marx, 1844).

About the existence of Religion in capitalist society, Marx insists that religion creates illusion that makes a situation when people specially the working class forget to revolt because of the alienation. Even, interest group always aiming to develop false consciousness involving themselves to spread a situation in such period when class conflict and its results belongs to the owner class (Bourgeoise). With the name of overtime (more time of actual working) in the production system, workers are exploited and little wage is provided, surplus totally goes to owner of the means of the production (Marx and Engels, 1957). Thus, the masses are oppressed, deprived from their actual privileges in the capitalist society. At the same time, this deprivation also obscures them to organize movement against the unlawful policies of capitalist class by 
which they can bring social change through collective action. Indeed Marx concludes that religion is the notion in which the masses are opiated (Rummel, 1977). Among the other theorist in the Marxist tradition, Fredrich Engels the benefactor of Marx has taken very complex position to describe the religion and religious functions in capitalism. Engels asserts that in some cases religion assists the movement of the deprived class identifying the result in Christianity (Marx and Engels, 1957). Subsequently, many followers of Marxism raise voice about the role of religious institutions with a soft acceptance its positive role to the development of social change as driving force. However, still few religions and religious denominations maintain gender equality, although they have patriarchal domination over the decades.

\section{Weberian Lens of Religion}

Like Durkheim, Max Weber (1864-1920) also contributes a lot for studying religious doctrine using his great intellectuals towards the humanity. As a rationalist Weber compares his ideas with Durkheim and Marx. He neither rejects the positive role of religion about promotion of society emphasized by functionnalism like Durkheim nor does he strongly support Marx's ideas about social inequality created by religion centralizing economic determinism. Weber emphasizes his writing complying on detailed historical and comparative examination of religion. Furthermore, mostly he focuses on the relationship between religion and economic life, arguing that religion can importantly contribute to the economic and social changes.

From economic aspects, religion is viewed as the idea generated and shaped from economy by Marx and in compare to Marx; religion is viewed as a reciprocal interaction by Weber. In his most famous work, "the protestant Ethic and the Spirit of Capitalism', Weber argues that in the Industrial Revolution, religion plays a vital role with the term 'Puritanism' (Weber, 1930). Additionally, the Puritanism solely helps the people to work hard securing more economic success. Thus, the western world issuing the purity in every sphere of work or as a sign of divine favor has developed rationality. From this rationalization, their business gets capital accumulation with the process of industrialization. The protestant ethics are followed to develop rationality that brings happiness and inspire the workforce to develop the capitalism. Again, Weber also exercises Indian and Chinese religious tradition aiming to explain the major obstacles to the economic rationality, he contends that social groups simply practice some collective affinities based on the characteristics of society that influence its religious status and rites, rituals (Weber, 1958). However, religion as active force can be change maker to the development of society.

\section{Symbolic Interactionist Perspective}

When Religion and society are perceived as macro aspects by the functional and conflict theorists' then symbolic interactionist theorists looks at the micro aspects. In general, from the socially construction of our world symbolic interactionists studies the symbols and interactions of people's everyday life. Inter-actionists argue in such way;

"beliefs and experiences are not sacred unless individuals in a society regard them as sacred" (McGivern, 2014).

For instance; the Star in Islam, the cross in Christianity, and the crescent are considered as sacred symbols because people literally practice such symbols to give meaning to life. Symbolic theorists also give priority how people interact using these symbols, gestures and pictures in their daily lives (Carter and Fuller, 2015). As earlier saying, symbolic interactionism is such kind of micro-level theoretical perspective in sociology studying individual's face-toface everyday interactions. Through this, someone can learn religious practices from a practiced fellow to new born member of society that helps to the religious socialization. By observing repeated and meaningful interactions between members of human society religious functions are broadly cultivated actively in a stable environment at any region of this planet. Following Ron McGivern (2014) people might be interested to such topics of study unlike the interactionist perspective do in the religious doctrine. For instance; a) Leaders of religion how interact with policy makers and researchers b) Evaluation of religion in every phase of life c) Expression of people using religious values in their daily social interactions d) Status of human being by religion either worshiper or practitioner e) Development in terms of social change. 


\section{Peter Berger's Sacred Canopy}

In the $20^{\text {th }}$ century, theoretical discussion of religion has achieved more popularity when Berger develops his "sacred canopy" as metaphor to understand the traditions of religion in a different manner for the first time in the sociological perspective (Berger, 1969). Ultimately, using phenomenological and interactionist traditions Berger has built this tradition reflecting on the contribution of human society to the development of unity and brotherhood among the community of the universe. In addition, he pretends that for building the world with peace, human society is working as important enterprise obeying the values of religion. Seemingly, it acts as a part of making a meaningful reality and people get the actual purpose of living in this moral community to spiritual happiness. Berger identifies this reality as dialectical because it has a strong correlation with other components as well. Thus, such dialectical process is related into three underlying movements of human society. First, the externalization process where human beings are interrelated to ongoing outpouring process both in the physical and the mental activities of man (Berger 1969: 4). Second, the objectivation, the act man gets the products of such activity considered as a reality and power and this product is free from the creator. Third, the internalization process, the way the individuals easily accept this socially constructed reality into their own inner life and become useful to develop cosmos or nomos. As a result, human society gets the opportunity to utilize such nomos in the universe to create and maintain the balance of meaningful order systems. According to Burger, nomos helps people from multiple danger situation and works as a shield against terror (Berger 1969: 22). In this regard, Berger defines religion by imposing the sacred cosmos in human life such a way;

"Religion is the human enterprise by which a sacred cosmos is established. Put differently, religion is cosmization in a sacred mode"

(Berger, 1967a).

So, the power of religion depends on how men stand before death, and walk accurately following the socially constructed reality the nomos or cosmos. Like Marx, Peter Berger argues that religion is a form of ideological framework used for the interpretation and understanding of the social world while in the past societies for example, religion is seen to have served chaotic and threatening world namely Death, Disaster and Disease (Berger, 1967b).

\section{CONCLUSION:}

From the above-mentioned discussion, it is evidently clear that religion as an institution deeply connected with people's beliefs, spirituality and pattern of controlling the sins, bad deed motivated usually by the religious priests. As functionalist, Durkheim concludes that religion is unified system of beliefs and practices that makes relation to sacred things among its followers. From Weberian lens, religion is such kind of force which works for social change and he has taken example from the development of European capitalism. The other proponent of conflict theory Marx critically views religion, defining a tool used by capitalist societies directly or indirectly to create and maintain social inequality. The interactionist Berger gives priority to the peace building functions of religion highlighting the nomos, by which our society can control social chaos spontaneously. Thus, religion is a cultural universal in all sorts of societies though the settings we experience are different in nature. However, functionalism, conflict, and interactionism perspective enrich the academician and students of social studies as always sociologists do for the society to understand religion.

\section{ACKNOWLEDGEMENT:}

Author would like to acknowledge and give warmest thanks to the colleagues of Department of Sociology, authority of Begum Rokeya University, Rangpur for providing insightful and valuable suggestions to continue such kind of particular research. Again, the author would also like to thank parents and relatives as a whole for their continuous support and understanding while writing this paper.

\section{CONFLICTS OF INTEREST:}

The author declares that there is no potential conflict of interest (such as honoraria, educational Grants, projects) in the subject matter or materials covered to publish this paper.

\section{REFERENCES:}

1) Anyanwu, H., (1999). African Traditional Religion from the Grassroots. Owerri Nigeria: Lasen 
Publishers.

2) Batson, C. D., Stokes, E. L., (2004). 'Religion: Its core psychological functions', in. New York: Guilford Press. Available at: https://www.researchgate.net/publication/2324242 34_Religion_Its_Core_Psychological_Functions

3) Berger, P. (1967a). The Social Construction of Reality. Penguin Books. Available at:

https://www.goodreads.com/book/show/51726.The _Social_Construction_of_Reality

4) Berger, P. (1967b). The Social Reality of Religion. Penguin Books. Available at:

https://dl1.cuni.cz/pluginfile.php/828102/mod_reso urce/content/1/Berger_Social_Reality.pdf

5) Berger, P. (1969). The sacred canopy: elements of a sociological theory of religion. Garden City New York: Doubleday. Available at:

https://www.researchgate.net/publication/2479917 60 The Sacred Canopy Elements of a Sociolog ical_Theory_of_Religion

6) Carter, M. J. and Fuller, C. (2015) 'Symbolic interactionism', Sociopedia, https://doi.org/10.1177/205684601561

7) Council of Europe, (2022). Religion and belief. https://www.coe.int/en/web/compass/religion-andbelief

8) Durkheim, E. (1912). The Elementary Forms of the Religious Life. Sage Publications. https://durkheim.uchicago.edu/Summaries/forms.ht $\underline{\mathrm{ml}}$

9) Durkheim, E. (1915). The Elementary Forms of the Religious Life. Available at:

https://www.gutenberg.org/files/41360/41360h/41360-h.htm

10) Emerson, M. O., Mirola, W. A., Monahan, S. C., (2016). 'Religion matters: What sociology teaches us about religion in our world', Religion Matters: What Sociology Teaches Us About Religion In Our World, pp. 1-258. https://doi.org/10.4324/9781315662909

11) Frost, W. J. (2005). Why Religions Facilitate War and How Religions Facilitate Peace: Friends Historical Library :: Swarthmore College. https://www.swarthmore.edu/friends-historicallibrary/why-religions-facilitate-war-and-howreligions-facilitate-peace

12) Gurr, T. R. (1993) Minorities at risk: a global view of ethnopolitical conflicts. Washington UniversePG I www.universepg.com
DC: Institute of Peace Press.

13) Herzog, P. S. et al., (2020) 'Studying religiosity and spirituality: A review of macro, micro, and meso-level approaches', Religions, 11(9), pp. 174. https://doi.org/10.3390/rel11090437

14) Hoffman, B. (1993). "Holy terror": the implications of terrorism motivated by a religious imperative' Worldwide Department of Defense Combating Terrorism Conference, Virginia Beach, VA. - 2006 Inside terrorism, revised and expanded edition. New York: Columbia University Press. Available at:

https://www.rand.org/pubs/commercial books/CB 386.html

15) Idowu, E. B. (1973). African traditional religion: A definition. London: SCIM Press. https://www.amazon.com/African-TraditionalReligion-Bolaji-Idowu/dp/0334000289

16) Hossain MK. (2020). Bhagabania, Nigamananda and Baha'i of Jashore in Bangladesh: A Study of Women, Asian J. Soc. Sci. Leg. Stud., 2(2), 4146. https://doi.org/10.34104/ajssls.020.041046

17) Krok, D. (2015). 'The Role of Meaning in Life Within the Relations of Religious Coping and Psychological Well-Being', Journal of Religion and Health, 54(6), p. 2292. https://doi.org/10.1007/S10943-014-9983-3

18) Marx, K. (1844). "Contribution to the Critique of Hegel's Philosophy of Right." Pp. 43-59 in Early Writings, edited by T. Bottomore. New York: McGraw-Hill. Available at: https://www.marxists.org/archive/marx/works/184 3/critique-hpr/intro.htm

19) Marx, K., Engels, F. (1957). On Religion. New York: Schocken Books. Available at: https://www.marxists.org/archive/marx/works/subj ect/religion/index.htm

20) McGivern, R. (2014). 'Chapter 15. Religion'. BCcampus. Available at:

https://opentextbc.ca/introductiontosociology/chapt er/chapter-15-religion/

21) Merton, R. K. (1957). Social Theory and Social Structure. Glencoe, IL: Free Press. Available at: https://edisciplinas.usp.br/pluginfile.php/4250035/ mod folder/content/0/Textos/Merton\%2C Social Theory and Social Structure.pdf?forcedownload=1

22) Miakhil P, Naeem A, and Bahar AA. (2022). 
Prestige restoration according to Afghan legal system, Asian J. Soc. Sci. Leg. Stud., 4(1), 12-17. https://doi.org/10.34104/ajssls.022.012017

23) O’Dea, T. F. (1966). The Sociology of Religion. Englewood Cliffs, New Jersey: Prentice Hall. https://www.amazon.com/Sociology-Religion-T-FODea/dp/0138213976

24) Parpart, J. L., Connelly, P. Barriteau, E. (2000). 'Theoretical perspectives on gender and development', p. 215. Available at: https://www.idrc.ca/sites/default/files/openebooks/ 272-4/index.html

25) Rummel, R. J. (1977). Marxism and Class Conflict, Beverly Hills, California: Sage Publications. Available at:

https://www.hawaii.edu/powerkills/CIP.CHAP5.H $\underline{\mathrm{TMm}}$
26) Silvestri, S. and Mayall, J. (2015). The Role of Religion in Conflict and Peace-Building. https://www.thebritishacademy.ac.uk/documents/3 25/Role-of-religion-in-conflict-peacebuilding 0 0.pdf

27) Snyder, H. (2019). 'Literature review as a research methodology: An overview and guidelines', Journal of Business Research, 104, pp. 333-339. https://doi.org/10.1016/J.JBUSRES.2019.07.039

28) Weber, M. (1930). The Protestant Ethic and the Spirit of Capitalism. Translated by T. Parsons. New York: Scribners.

https://selforganizedseminar.files.wordpress.com/2 011/07/weber_protestant ethic.pdf

29) Weber, M. (1958). The Religion of India. Translated by H. H. Gerth and D. Martindale. Glencoe, IL: Free Press. Available at:

https://www.worldcat.org/title/religion-of-indiathe-sociology-of-hinduism-and-buddhism/oclc/ 492322\#borrow

Citation: Barman RP. (2022). Religion from sociological perspectives: an overview, Asian J. Soc. Sci. Leg. Stud., 4(2), 24-31. https://doi.org/10.34104/ajssls.022.024031 @) () 